aggressive treatment with intravitreal and systemic antibiotics combined with steroid therapy.

Endogenous $E$ coli endophthalmitis appears to occur almost exclusively in diabetics, and is invariably related to a urinary tract infection. Treatment of any infection in diabetics should be aggressive and care should be taken to cover the likely pathogens. The outcome of $E$ coli

1 Zakka K, Hirose T. Bilateral endogenous Escherichia coli endophthalmitis. Ann Ophthalmol 1985; 17: 212-5.

2 Hornblass A, To K, Code DJ, et al. Endogenous en dophthalmitis in subacute bacterial endocarditis. $A m \mathcal{f}$ Ophthalmol 1989; 108: 338-9.

3 Williams DN, Geddes AM. Meningococcal meningitis complicated by pericarditis, panophthalmitis and arthritis $B M \mathcal{f}$ 1970; 2: 93 .

4 Johnson AG. Metastatic septic endophthalmitis. South Med f 1969; 62: 879-80.

5 Deutsch D, Adler S, Teller J, et al. Endogenous candidal endophthalmitis. Ann Ophthalmol 1989; 21: 260-8.

6 Park SB, Searl S, Aquavella JV, Erdey RA. Endogenous endophthalmitis caused by Escherichia coli. Ann Ophthalmol 1993; 25: $95-9$. endogenous endophthalmitis is invariably poor and so any deterioration in vision should be assessed promptly as it is not necessarily painful. The alteration of the red reflex to a whitish reflex is an important early sign. In settings where patients cannot communicate, periodic examination of the fundi should be undertaken. Thankfully this condition remains rare.

7 Fanning WL, Stubbert J, Irwin ES, Aronson MD. A case of bilateral Escherichia coli endogenous endophthalmitis. Am $\mathcal{F}$ Med 1976; 61: 295-

8 Cohen P, Kirshner J, Whiting G. Bilateral endogenous Escherichia coli endophthalmitis. Arch Intern Med 1980; 140 1088-9.

9 Lye WC, Chan RKT, Lee EJC, Kumarasinghe G. Urinary tract infections in patients with diabetes mellitus. $\mathcal{F}$ Infect 1992; 24: $169-74$.

10 Puliafito CA, Baker AS, Haaf J, Foster CS. Infectious endophthalmitis: review of 36 cases. Ophthalmology 1982; 89: $1055-66$.
Epsom General

Hospital, Epsom,

Surrey, KT18 7EG,

UK

Department of

Chemical Pathology

LR Ranganath

GA Lewis

BT Nobbs

PF Goddard

Department of

Medicine for the

Elderly

DC Rangedera

\title{
Elevated serum prostate-specific antigen and pancreatic carcinoma
}

\author{
LR Ranganath, GA Lewis, BT Nobbs, PF Goddard, DC Rangedera
}

\section{Summary \\ We report a case of elevated serum prostate-specific antigen-like immuno- reactivity in a man with a disseminated pancreatic carcinoma}

Keywords: prostate-specific antigen, prostatic biopsy, pancreas

Measurement of serum prostate-specific antigen (PSA) is said to be a specific and sensitive tool in the diagnosis of prostatic cancer. ${ }^{1}$ It has been said that PSA is not present in any other normal tissue obtained in men apart from the prostate, nor is it produced by cancers of the breast, lung, colon, rectum, stomach, thyroid or pancreas. ${ }^{2}$

\section{Case report}

A 79-year old man was admitted with a fourmonth history of weight loss, diarrhoea and abdominal pain. Physical examination and investigations including ultrasound, computed tomography (CT) of abdomen and fine needle biopsy of a retroperitoneal mass suggested the diagnosis of adenocarcinoma of the pancreas with multiple secondary metastases in the liver. Bone scans and chest X-ray excluded any skeletal or thoracic spread. Routine haematology and biochemistry investigations were nor- mal except for serum $\gamma$-glutamyl transpeptidase, amylase and erythrocyte sedimentation rate which were noted to be $85 \mathrm{U} / 1$ (ref range $1-28$ ), $150 \mathrm{IU} / 1$ (ref range 30-110) and $33 \mathrm{~mm} / \mathrm{h}$, respectively. Serum PSA and acid phosphatase measurements were requested at the time of admission and showed an unexpectedly high value for PSA. Prostate-specific acid phosphatase levels of 1.6 and $2.2 \mathrm{IU} / 1$ (tartrate labile fraction) (ref range $0.1-2.8$ )

\begin{tabular}{|l|}
\hline Causes of raised serum PSA \\
\hline Analytical interference \\
Prostatic \\
- prostatitis \\
- prostate infarcts \\
- benign enlargement \\
- carcinoma \\
Non-prostatic \\
- breast milk \\
- salivocrine sweat glands ${ }^{\star}$ \\
- para-urethral gland \\
- renal cell adenocarcinoma \\
- breast tumours \\
- apocrine sweat gland tumours \\
${ }^{\star}$ not detected to be high in blood \\
$\star_{\star}^{\star}$ only with assays using polyclonal antisera \\
\hline
\end{tabular}


were noted on two occasions while serum PSA levels of 233, 206 and $272 \mu \mathrm{g} / 1$ (ref range 1.04.0) were shown on separate occasions. The patient denied any prostatic symptoms and evaluation by digital rectal examination, transabdominal and transrectal ultrasonography as well as needle biopsy (four cores of prostatic tissue) showed no evidence of carcinoma of prostate. He became extremely ill with marked weight loss during his hospital stay prior to his demise.

Serum PSA measurements are routinely analysed in our laboratory by using a Hybritech $^{\mathrm{TM}}$ immunoenzymetric assay (Tandem ${ }^{\mathrm{TM}}$ E PSA) which uses monoclonal antisera of mouse origin. Measurement of serum PSA using an immunoradiometric assay kit (CIS Biointernational ${ }^{\mathrm{TM}}$ ) in a different laboratory was concordant with measurements in our laboratory. Tests for heterophilic antibody using mouse serum were negative. Serial dilution of serum for PSA measurements was linear and excluded non-heterophilic antibody interference.

\section{Discussion}

The history, physical examination and investigations performed in this man showed an apparent carcinoma of pancreas with secondary spread into the liver. The unexpected elevation of serum PSA was associated with the absence of prostatic symptoms in the history as well as a normal digital rectal examination. A transabdominal and transrectal ultrasound of the prostate showed a normal sized prostate. Prostatic needle biopsies which enabled four cores of prostatic tissue to be sampled showed no evidence of malignancy. Acid phosphatase has been shown to increase reliably in those with disseminated prostatic disease $^{3}$ but our patient had normal values on two occasions.

1 Chisholm GD, Carne SJ, Fitzpatrick JM, et al. Prostate disease: management options for the primary healthcare team. Postgrad Med f 1995; 71: 136-42.

2 Kramer BS, Brown ML, Prorok PC, Potosky AL, Gohagan JK. Prostate cancer screening: what we know and what we need to know. Ann Intern Med 1993; 119: 914-23.

Med DW, Hen in

Moss DW, Henderson AR, Kachmar JF. In: Teitz NW, ed Fundamentals of clinical chemis

4 Armbruster DA. Prostate-specific antigen: biochemistry, armbruster DA. Prostate-specific antigen: biochemistry, analytical methods,

5 Graves HCB. Nonprostatic sources of prostate-specific 5 Graves HCB. Nonprostatic sources of prostate-specific Chem 1995; 41: 7-9.

6 Van Krieken JH. Prostate marker immunoreactivity in salivary gland neoplasms. A rare pitfall in immunohistochemistry. Am f Surg Pathol 1993; 17: 410-4.

7 Iwakiri J, Granbois K, Wehner N, et al. An analysis of urinary prostate specific antigen before and after radical prostatectomy: evidence for secretion of prostate specific antigen by the periurethral glands. $\mathcal{f}$ Urol 1993; 149: 783-6.
The investigations on the PSA analysis in this man excluded analytical interference and confirmed that our routine laboratory methodology was consistently detecting PSA-like immunoreactivity.

PSA is described as prostate-specific although not prostate cancer specific. ${ }^{4}$ There is, however, increasing recognition that nonprostatic tissues also produce PSA. ${ }^{5}$ PSA-like immunoreactivity has been shown in breast milk, breast tumours, and apocrine sweat glands. ${ }^{5}$ Histochemical staining in carcinoma of salivary and Skene's glands has shown PSAlike immunoreactivity ${ }^{6,7}$ although elevation of PSA has not been seen in the blood. Rasmuson and colleagues have demonstrated elevated PSA values in sera of women with renal cell cancers using polyclonal antisera, ${ }^{8}$ although these measurements could not be reproduced with assays using monoclonal antisera. The Hybritech $^{\mathrm{TM}}$ kit for PSA immunoreactivity measurement specifically states that PSA is not present in pancreatic cancer tissue. Noncancerous pancreatic tissue is rich in kallikrein (a peptide belonging to the same superfamily as PSA), but has not been shown to contain PSA. ${ }^{9}$

Recent molecular studies have located the PSA gene to human chromosome 19, giving both sexes two copies of this gene. ${ }^{10}$ In addition, androgen-response element sequences have been separately identified in the promoter region of the PSA gene ${ }^{11}$ and human androgen receptor has been shown to specifically bind to these promoter sequences. ${ }^{12}$ These findings suggest that PSA may be expressed in tissues where an appropriate steroid receptor is present. It is tempting to speculate that neoplastic pancreatic tissue in this man may have secreted PSA-like immunoreactive substance.

8 Rasmuson T, Grankvist K, Lingberg B. False-positive prostate specific antigen values in the sera of women with renal cell carcinoma. F Urol 1994; 151: 704-5.

9 Schedlich LJ, Bennetts BH, Morris BJ. Primary structure of a human glandular kallikrein gene. DNA 1987; 6: 429-37.

10 Riegman PHJ, Vlietstra RJ, Klasen $\mathrm{P}$, et al. The prostatespecific antigen gene and the human glandular kallikrein-1 pene are tandemly located on chromosome 19. FEBS Let 1989; 247: $123-6$.

11 Murth P, Tindall DJ, Young CYF. Androgen induction of a human prostate-specific kallikrein hKLK2: characterisation of an androgen response element in the 5 ' promoter tion of an androgen response element in the 5' prom

12 Luke MC, Coffey DS. Human androgen receptor bindin 2 Luke MC, Coffey DS. Human androgen receptor binding antigen. $\mathcal{f}$ Androl 1994; 15: $41-51$. 